\title{
Study on Enhanced Antibacterial and Cytotoxicity of Pure and Cadmium Doped Cerium Oxide against Gram-Positive and Gram-Negative Bacteria
}

\author{
Killivalavan Govindarasu1, Kavitha Gnanasekaran'2, Sathyaseelan Balaraman ${ }^{3 *}$, \\ Baskaran Iruson", Senthilnathan Krishnamoorthy5, Rameshkumar Gubendiran', \\ Babu Padmaraj ${ }^{2}$, Elayaperumal Manikandan ${ }^{6,7}$, Sivakumar Dhananjayan ${ }^{8}$
}

${ }^{1}$ Department of Physics, Bharathiar University, Coimbatore, India

${ }^{2}$ P. G. Research \& Department of Physics, A. M. Jain College, Meenambakkam, India

${ }^{3}$ Department of Physics, University College of Engineering Arni (A Constituent College of Anna University Chennai), Arni, India

${ }^{4}$ Department of Physics Arignar Anna Govt. Arts College, Cheyyar, Tamil Nadu, India

${ }^{5}$ Department of Physics, VIT University, Vellore, India

${ }^{6}$ Department of Physics, Thiruvalluvar University, TUCAS Campus, Thennangur, India

${ }^{7}$ UNESCO UNISA Africa Chair in Nanosciences \& Nanotechnology, College of Graduate Studies, University of South Africa, Muckleneuk Ridge, Pretoria, South Africa

${ }^{8}$ Department of Physics, Sree Krishna College of Engineering, Unai, Anai, India

Email: ^bsseelan03@gmail.com

How to cite this paper: Govindarasu, K., Gnanasekaran, K., Balaraman, S., Iruson, B., Krishnamoorthy, S., Gubendiran, R., Padmaraj, B., Manikandan, E. and Dhananjayan, S. (2019) Study on Enhanced Antibacterial and Cytotoxicity of Pure and Cadmium Doped Cerium Oxide against Gram-Positive and Gram-Negative Bacteria. Soft Nanoscience Letters, 9, 1-16. https://doi.org/10.4236/snl.2019.91001

Received: December 26, 2018

Accepted: January 28, 2019

Published: January 31, 2019

Copyright $\odot 2019$ by author(s) and Scientific Research Publishing Inc. This work is licensed under the Creative Commons Attribution International License (CC BY 4.0).

http://creativecommons.org/licenses/by/4.0/

\begin{abstract}
Pure and Cadmium (Cd) doped Cerium oxide nanoparticles (CeNPs) have been synthesised by the simple chemical co-precipitation technique. Cadmium ions of concentrations 1,3 and $5 \mathrm{~mol} \%$ were doped to investigate their influence on the structural and optical properties of $\mathrm{CeO}_{2}$. The synthesised samples have been subjected to X-ray diffraction (XRD), scanning electron microscopy (SEM), energy dispersive X-ray (EDX) analysis and high-resolution transmission electron microscopy (HRTEM). The XRD and Raman patterns have witnessed the cubic structure of the cerium oxide nanoparticles. The average particle size of $\mathrm{CeO}_{2}$ was found to be around $10 \mathrm{~nm}$. SEM image has also ascertained that the grain size of pure $\mathrm{CeO}_{2}$ appeared is bigger than that of the Cd-doped, which intern indicates the grain growth upon doping. Besides, the antibacterial activity of the cadmium doped cerium oxide nanoparticles against some human pathogens revealed that they have exhibited the maximum zone of inhibition against gram-positive bacteria than the gram-negative species. Further, the cytotoxic effect of Cd-doped $\mathrm{CeO}_{2}$ sample is examined in cultured (MCF-7, A549 and Hep-2) cell.
\end{abstract}




\section{Keywords}

Co-Precipitation, XRD, SEM, HRTEM, Antibacterial Activity

\section{Introduction}

Of late, nanotechnology has been the primary focus, especially, on biomedical related research activities. It has been well demonstrated that the nanomaterial's exhibited several interesting properties and they were exploited in the field of life science research, biology and medicine [1]-[6]. Thus, these nanomaterials find a wide range of applications which include luminescent biomarkers, drug delivery systems, tissue engineering, etc [7]. Recently, owing to the enormous developments in nanoscience and nanotechnology, the field of nanomedicine plays an indispensable role to investigate the novel drugs to augment the conventional therapies, namely, surgical interventions, radiation and cytotoxic chemotherapy which are considerably effective in the cancer treatment [8] [9] [10] [11] [12]. It was reported that the Cerium oxide $\left(\mathrm{CeO}_{2}\right)$ and many rare earth metal oxides of lanthanide series were found to exhibiting face-centered cubic fluorite-type crystal structures. Cerium oxide nanoparticles (CeNPs) originated from the variable valence states $(3+$ and $4+$ ) of cerium element. These nanoparticles could be explored for various applications in industrial areas such as the catalysts, polishing agents, fuel cells, ultraviolet absorbents in sunscreen lotions, gas sensors, etc. Its redox activity $\left(\mathrm{Ce}^{3+} / \mathrm{Ce}^{4+}\right.$ redox switch) along with the oxygen vacancies due to surface defects has led to various biological activities, namely, anti-inflammation, antiapoptotic, antioxidant property etc [13]. In literature, $\mathrm{CeO}_{2}$ nanoparticles were prepared by several methods namely; hydrothermal synthesis [14], Co-precipitation technique [15] and Solvothermal Methods [16] [17]. Of these techniques, co-precipitation method is a quite simple process, low in cost, easy to prepare and industrially viable. In the present work, Cd-doped $\mathrm{CeO}_{2}$ nanoparticles have been prepared using co-precipitation technique. The effect of Cadmium doping on the structural and morphological properties of $\mathrm{CeO}_{2}$ has been studied using X-ray diffraction (XRD), Raman spectroscopy, SEM and HRTEM analysis. The biological activity against certain human pathogen was also analysed.

\section{Materials and Method}

\subsection{Materials}

Cadmium acetate $\left(\mathrm{Cd}\left(\mathrm{CH}_{3} \mathrm{COO}\right)_{2} \cdot 2 \mathrm{H}_{2} \mathrm{O}\right.$, Merck, pure), Cerium(III) Nitrate Hexahydrate $\left(\mathrm{Ce}\left(\mathrm{NO}_{3}\right)_{3} \cdot 6 \mathrm{H}_{2} \mathrm{O}\right.$, Spectrochem, $99 \%$ purity), Sodium hydroxide (NaOH, Merck, 99.99\% purity) and Polyethylene glycol (PEG) were taken as the initial reagents to synthesize the $\mathrm{Cd}_{(1-x)} \mathrm{Ce}_{\mathrm{x}} \mathrm{O}$ nanostructure. Deionized water was used as the solvent to prepare solutions of precursors. 


\subsection{Synthesis Procedure}

In a typical synthesis process, appropriate quantities of $\mathrm{Cd}\left(\mathrm{CH}_{3} \mathrm{COO}\right)_{2} \cdot 2 \mathrm{H}_{2} \mathrm{O}$ and $\mathrm{Ce}\left(\mathrm{NO}_{3}\right)_{3} \cdot 6 \mathrm{H}_{2} \mathrm{O}$ were grounded uniformly, mixed and finally dissolved in $350 \mathrm{ml}$ distilled water with the assistance of continuous magnetic stirring. Measurable amount of Polyethylene glycol (PEG) and $\mathrm{NaOH}$ solution was then added into the above solution and the resulting one was kept under sonification for $30 \mathrm{~min}-$ utes so as to achieve the $\mathrm{pH}$ value of 11 . The prepared solution was then transferred into a Teflon-lined autoclave and heated at $100^{\circ} \mathrm{C}$ for $22 \mathrm{hrs}$. The various compositions of the Cadmium substituted samples have been represented by a given formula $\mathrm{Cd}_{(1-\mathrm{x})} \mathrm{Ce}_{\mathrm{x}} \mathrm{O}$ with $\mathrm{x}$ being 0, 1.0, 3.0 and 5.0 mole percentage. The final products were obtained after washing and filtering several times with distilled water and anhydrous ethanol. Then it was dried at $100^{\circ} \mathrm{C}$ in vacuum atmosphere.

\subsection{Antibacterial Activity of $\mathrm{Cd}$ Doped $\mathrm{CeO}_{2} \mathrm{NPs}$}

The antibacterial activities of synthesized $\mathrm{Cd}$ doped $\mathrm{CeO}_{2}$ NPs were studied against Gram-positive (G+ve) ( $S$. aureus. Staphylococcus aureus) and Gram-negative (G-ve) (E. col: Escherichia coli, P. aeruginosa: Pseudomonas aeruginosa) strains by disk diffusion method. In brief, the bacterial strains were cultured in nutrient broth at $37^{\circ} \mathrm{C}$ until the culture reached $1.5 \times 10^{8}$ colony forming units (CFU) per milliliter. About $20 \mathrm{~mL}$ of autoclaved molten nutrient agar was poured into the Petri dishes and allowed to cool. All of the bacterial cultures were swapped over solidified agar medium. Later, disks were loaded with $\mathrm{Cd}$ doped $\mathrm{CeO}_{2}$ NPs solution of $20 \mu \mathrm{g} / 5 \mu \mathrm{L}$ through micropipette. The plates were incubated at $37^{\circ} \mathrm{C}$ for 24 hours and the zones of inhibition (ZOIs) around the disks were measured.

\subsection{Cell Culture and Cell Line Maintenance}

Breast cancer cells (MCF-7), Human Lung cancer cells (A549) and Human Larynx Carcinoma cancer cells (Hep-2) were obtained. Then, these cell lines were grown as a monolayer in Dulbecco's modified Eagle's medium (DMEM: Himedia Laboratories, Mumbai, India), medium which was supplemented with $10 \%$ fetal bovine serum , $100 \mathrm{U} / \mathrm{mL}$ penicillin, and $100 \mu \mathrm{g} / \mathrm{mL}$ streptomycin (Hi Media Laboratories Mumbai, India) cells grown at $37^{\circ} \mathrm{C}$ in incubator under $5 \% \mathrm{CO}_{2}$ with high humidity [18] [19] [20].

\subsection{MTT Assay Method for Evaluation of Cell Viability and Cytotoxicity}

The anticancer activity of samples on MCF-7, A549 and Hep-2 cells was determined by the MTT (3-(4,5-dimethyl thiazol-2yl)-2, 5-diphenyl tetrazolium bromide) assay was used to assess the cytotoxicity by Mosmann [21] [22]. There Cells $\left(1 \times 10^{5} /\right.$ well $)$ were plated in $0.2 \mathrm{ml}$ of the cells with concentration of $1 \times$ $10^{5}$ cells/ml were plated in well 96 -well plates. The plates were incubated for 24 
hrs in 5\% $\mathrm{CO}_{2}$ incubator for cytotoxicity. After incubation, normal breast (MCF-7, A549 and Hep-2) cells were cultured in 1:1 mixture of dimethyl sulfoxide (DMSO). Then, they were added to each well and mixed well by micropipette [23]. The percentage of viable cells was visualized by the development of purple color due to formation of formazan crystals. The suspension was transferred to the cuvette of a spectrophotometer and observed significant variance/instability in the optical density (OD). Measurements were performed and the concentration required for a $50 \%$ inhibition of viability $\left(\mathrm{IC}_{50}\right)$ was determined and used for the bioassays.

\subsection{Morphological Cross Section of Apoptotic Cells by Acridine Orange (AO) and Ethidium Bromide (EB) Staining}

The cross sectional morphology of apoptotic cells was carried by AO/EB double staining method which was proposed by Spector et al. [24]. The cells were treated with $\mathrm{IC}_{50}$ Concentration of $\mathrm{Cd}$ doped $\mathrm{CeO}_{2}$ for 24 hours in a humidified atmosphere of $5 \% \mathrm{CO}_{2}$ at $37^{\circ} \mathrm{C}$ incubation. The cells were harvested and washed with cold PBS. Cell pellets were diluted with PBS concentration of $5 \times 10^{6}$ cells $/ \mathrm{mL}$ and mixed with $10 \mu \mathrm{l}$ of AO/EB solution $(3.8 \mu \mathrm{M}$ of $\mathrm{AO}$ and $2.5 \mu \mathrm{M}$ of EB in PBS). The cross-section morphology of apoptotic was investigated by fluorescence microscope (Carl Zeiss, Axioscope 2 plus) with UV (450 - $490 \mathrm{~nm}$ ) [25].

\subsection{Morphological Cross Section of Apoptotic Cells by DAPI Staining}

In addition to the above study, the morphological cross-section of apoptotic cells was also examined by DAPI staining. 4',6-diamidino-2-phenylindole (DAPI) staining was carried out according to the method described by Papi et al. with some modifications [26]. Hep-2 cells were grown on sterile glass slides overnight and treated for 48 hours with sulforaphene (in serum free media) concentration of $\mathrm{IC}_{50}(33.8 \mu \mathrm{M})$. The cells were incubated for 48 hours in a humidified atmosphere of $5 \% \mathrm{CO}_{2}$ at $37^{\circ} \mathrm{C}$. At the end of the incubation, cells were fixed with $4 \%$ paraformaldehyde and then phosphate buffered saline (0.1\% in PBS). Cells were finally stained using DAPI in PBS $(2.5 \mu \mathrm{g} / \mathrm{mL})$ and allowed to stand for $20 \mathrm{~min}$ in a dark condition. Finally, morphological cross-section reforms were observed by fluorescence microscopy. (Magnification $\times 400$ ) (Zeiss, Oberkochen, Germany) [27].

\subsection{Characterization of Cd Doped $\mathrm{CeO}_{2} \mathrm{NPs}$}

Powder X-ray diffraction (XRD) measurements were carried out for pure and cadmium doped $\mathrm{CeO}_{2}$ samples using a Bruker D8 advance diffractometer with monochromatized $\mathrm{Cu} \mathrm{K} \alpha$ radiation $(\lambda=1.5418 \AA)$. The X-ray source was operated at $40 \mathrm{kV}$ with a current of $40 \mathrm{~mA}$. The measurements were performed by $\theta / 2 \theta$ scans in the $2 \theta$ range from $20^{\circ}$ to $80^{\circ}$ with a step size of $0.02^{\circ}$ and at a scan rate of $2^{\circ} / \mathrm{min}$. The micrographs of cadmium doped $\mathrm{CeO}_{2}$ samples were also 
obtained using the scanning electron microscope (Model: JEOL-JSM 6360) and high-resolution transmission electron microscope-HRTEM (Model: JEOL/JEM 2100). Elemental analysis was carried out for ascertaining the concentrations of cadmium in $\mathrm{CeO}_{2}$ materials with the aid of energy dispersive $\mathrm{X}$-ray spectroscopy equipped with scanning electron microscopy. Micro-Raman spectra were recorded in backscattering configuration and analyzed using a JobinYvon T64000 spectrometer equipped with the nitrogen cooled charge-coupled-device detector. The normal and apoptotic cells have been visualised using an upright fluorescent microscope (Nikon Eclipse, Inc., Japan) at $40 \times$ magnification with the excitation filter at $510-590 \mathrm{~nm}$.

\section{Results and Discussion}

\subsection{X-Ray Diffraction (XRD) Analysis on Pure and Cd Doped $\mathrm{CeO}_{2}$}

XRD patterns of pure and $\mathrm{Cd}$ doped $\mathrm{CeO}_{2}$ nanoparticles at different concentrations of $\mathrm{Cd}(1,3$ and $5 \mathrm{~mol} \%)$ are shown in Figure 1. The structural properties of the pure and $\mathrm{Cd}$ doped $\mathrm{CeO}_{2}$ nanoscale materials were determined through XRD measurements. The synthesized product exhibits the diffraction peaks with parallel planes (hkl) which indicate the presence of $\mathrm{CeO}_{2}$ compound with cubic

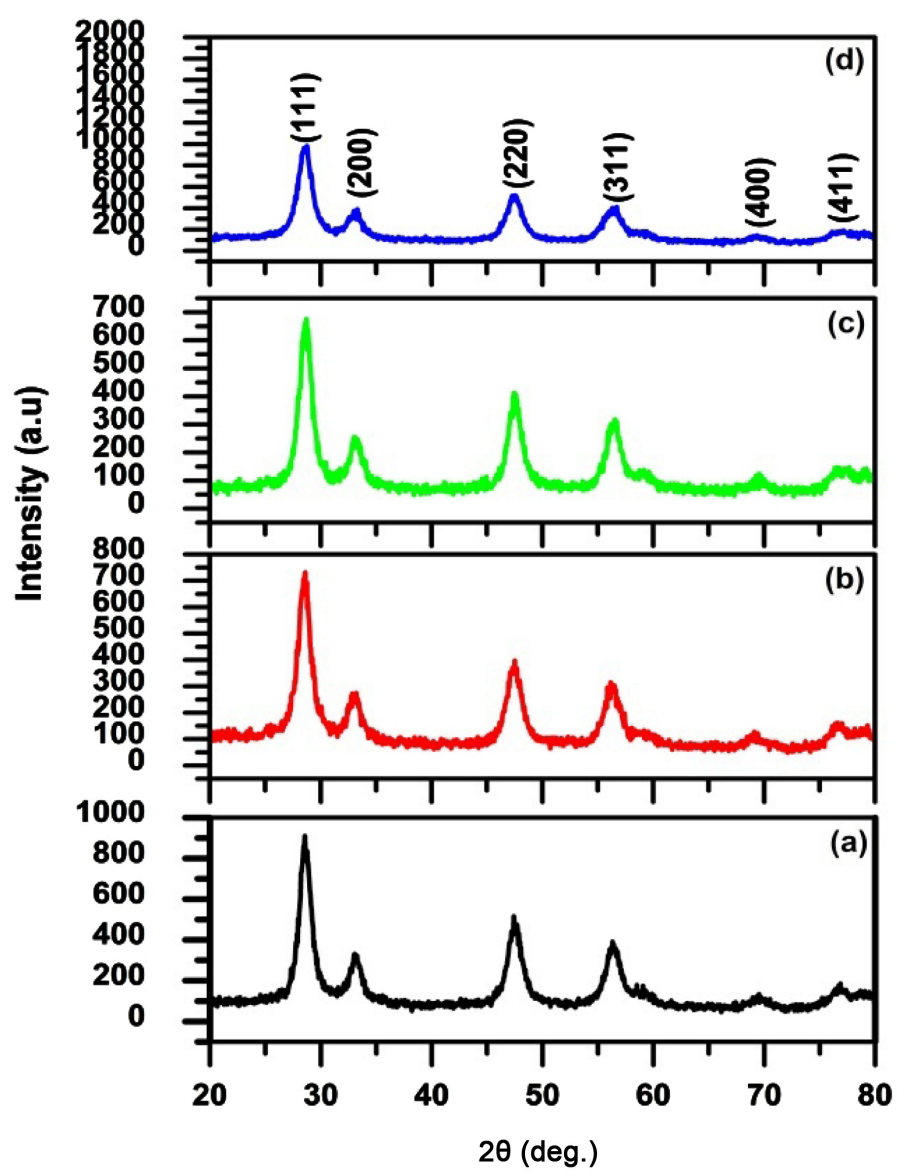

Figure 1. XRD patterns of the $\mathrm{CeO}_{2}$ nanoparticles containing: (a) $0 \%$, (b) $1.0 \%$, (c) $3.0 \%$, and (d) $5.0 \%$ of Cd. 
$\mathrm{NaCl}$ structure (JCPDS card number: 34-0394). The intensities of (111), (200), (220), (311), (400) and (411) peaks in the 1,3 and 5\% $\mathrm{Cd}$ added $\mathrm{CeO}_{2}$ were found to be prominent. It can be seen from the XRD pattern that the positions of the peaks have been shifted towards the higher $2 \theta$ value with increase in " $\mathrm{Cd}$ " content. In Figure 1, the "d" values are calculated using (111) peak for different concentration of $\mathrm{Cd}$ ions doped in $\mathrm{CeO}_{2}$ matrix. The $\mathrm{d}_{(111)}$ values are found to decrease with the Cd content. Thus, the decreasing trend of $\mathrm{d}_{(111)}$ values reflects that lattice parameters decrease with Cd doping which is in good agreement with the earlier reported results [28] [29] [30]. XRD results also provide a clue that the $\mathrm{Cd}$ ions replace some of the $\mathrm{Ce}$ ions in the $\mathrm{CeO}_{2}$ matrix and ruled out the formation of any other crystalline phase. The average crystalline sizes of the pure and $\mathrm{Cd}$-doped $\mathrm{CeO}_{2}$ have been found in the range of $20-42 \mathrm{~nm}$ using Scherrer's equation [31].

$$
D=0.89 \lambda /(\beta \cos \theta) .
$$

Here $\theta$ is the Bragg diffraction angle, $\beta$ is the peak width at half maxima. The broadening of the diffraction peaks with increase in the concentration of dopant reveals the formation of nanocrystals with the phase $\mathrm{CeO}_{2}$.

\subsection{Raman Studies on Pure and Cd Doped $\mathrm{CeO}_{2} \mathrm{NPs}$}

Figure 2 shows the Raman spectra of the pure and $\mathrm{Cd}(0,1,3$ and $5 \mathrm{~mol} \%)$ doped $\mathrm{CeO}_{2}$ nanoparticles in the frequency range $200-1200 \mathrm{~cm}^{-1}$. The $\mathrm{CeO}_{2}$ exhibited a strong Raman spectrum at $455 \mathrm{~cm}^{-1}$ because of the $\mathrm{F}_{2 \mathrm{~g}}$ Raman active mode of the fluorite structure [32]. It also exhibits a shoulder like scattering vibrations at $\approx 602 \mathrm{~cm}^{-1}$ and $1050 \mathrm{~cm}^{-1}$ owing to the normal Raman inactive (IR active) transverse and longitudinal optical phonon modes, respectively, at the Brillouin zone center [33]. The spectrum of $\mathrm{Cd}$ doped $\mathrm{CeO}_{2}$ showed the prominent peaks at $452 \mathrm{~cm}^{-1}$ and a weak band $602 \mathrm{~cm}^{-1}, 1043 \mathrm{~cm}^{-1}$. The band at 452 $\mathrm{cm}^{-1}$ represents the triply degenerate $\mathrm{F}_{2 \mathrm{~g}}$ mode and it is identified as a symmetric breathing mode of the $\mathrm{O}$ atoms around $\mathrm{Ce}$ ions [34]. The weak band observed near 602 and $1043 \mathrm{~cm}^{-1}$ could be attributed to a non-degenerate longitudinal optical (LO) mode of $\mathrm{CeO}_{2}$ [35].

\subsection{SEM Analysis on Pure and Cd Doped $\mathrm{CeO}_{2} \mathrm{NPs}$}

Figures 3(a)-(d) represent the overall surface morphology of pure and Cd doped $\mathrm{CeO}_{2}$ nanoparticles. The figures reveal that the pure $\mathrm{CeO}_{2}$ compound consists of large aggregates transformed to more fine aggregates up on increasing the concentration of dopant. The images also show the agglomeration of homogeneous particles with a size distribution of around $1 \mu \mathrm{m}$ in diameter. Figure 4 shows the EDX spectrum of $\mathrm{Cd}$ doped $\mathrm{CeO}_{2}$ and it confirms the presence of $\mathrm{Cd}$ ions in the $\mathrm{CeO}_{2}$ matrix. Further, the estimated compositions do exist in the sample in respect of Cadmium, cerium and oxygen elements. The atomic \% of $\mathrm{Cd}, \mathrm{Ce}$, and $\mathrm{O}$ are 1.20, 24.45 and 74.35, respectively, for $3 \%$ of Cd doping. 


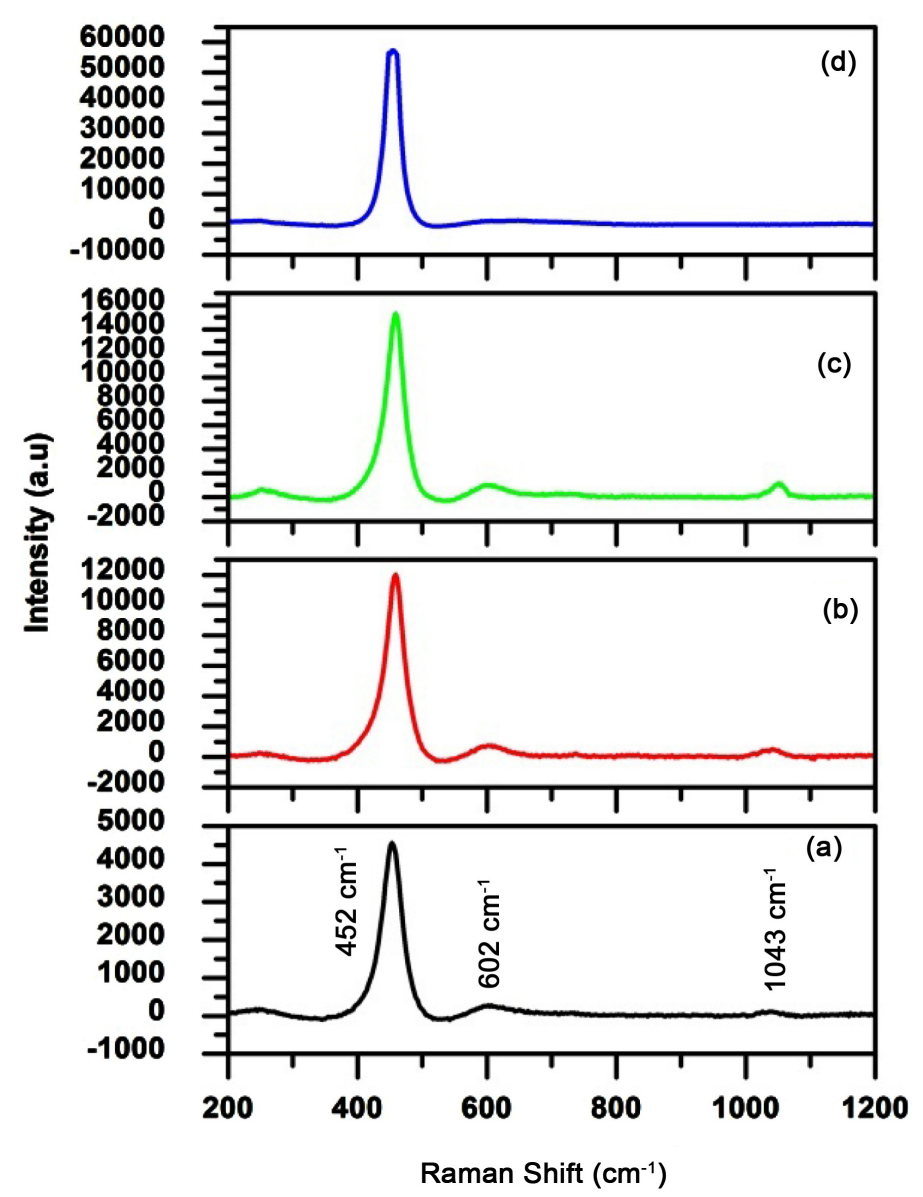

Figure 2. Raman spectra of the $\mathrm{CeO}_{2}$ nanoparticles containing: (a) $0 \%$, (b) $1.0 \%$, (c) $3.0 \%$, and (d) $5.0 \%$ of Cd.

\subsection{HRTEM Analysis on Pure and Cd Doped $\mathrm{CeO}_{2}$ NPs}

HRTEM images of the samples shown in Figure 5(a) and Figure 5(c) provide the average crystalline size for pure and doped $\mathrm{CeO}_{2}$ and it confirms that the average crystalline size of $\mathrm{Cd}$ doped nanoparticles is smaller than that of pure $\mathrm{CeO}_{2}$. The particle size of pure and $\mathrm{Cd}$ doped $\mathrm{CeO}_{2}$ is $6 \mathrm{~nm}$ and $5 \mathrm{~nm}$, respectively. The results are in good agreement with XRD data. It was observed that size of particles decreases with increase of dopant concentrations. Figure 5(b) and Figure 5(d) depicts SAED patterns of $\mathrm{CeO}_{2}$ and $\mathrm{Cd}$ doped $\mathrm{CeO}_{2}$ and it confirms the fluorite structure of $\mathrm{CeO}_{2}$ and the ring patterns showed (111), (200), (220) and (311) planes of cubical unit cell.

\subsection{Antibacterial Analysis of $\mathrm{Cd}$ Doped $\mathrm{CeO}_{2} \mathrm{NPs}$}

The antibacterial assay was performed against $\mathrm{G}+\mathrm{ve}$ and $\mathrm{G}-\mathrm{ve}$ bacterial entities using $\mathrm{Cd}$ doped $\mathrm{CeO}_{2}$ NPs sample loaded at a concentration of $20 \mu \mathrm{g} / 05 \mu \mathrm{L}$ on disks. Figure 6 and Figure 7 reflect the measurements in size of $\mathrm{ZOI}$ around $\mathrm{Cd}$ doped $\mathrm{CeO}_{2} \mathrm{NPs}$ poured disks. The synthesized $\mathrm{Cd}$ doped $\mathrm{CeO}_{2} \mathrm{NPs}$ have proven efficiency and comparatively low genotoxic and cytotoxic behavior toward healthy cells, when compared to $\mathrm{Cd}$ doped $\mathrm{CeO}_{2} \mathrm{NPs}$ synthesized by 


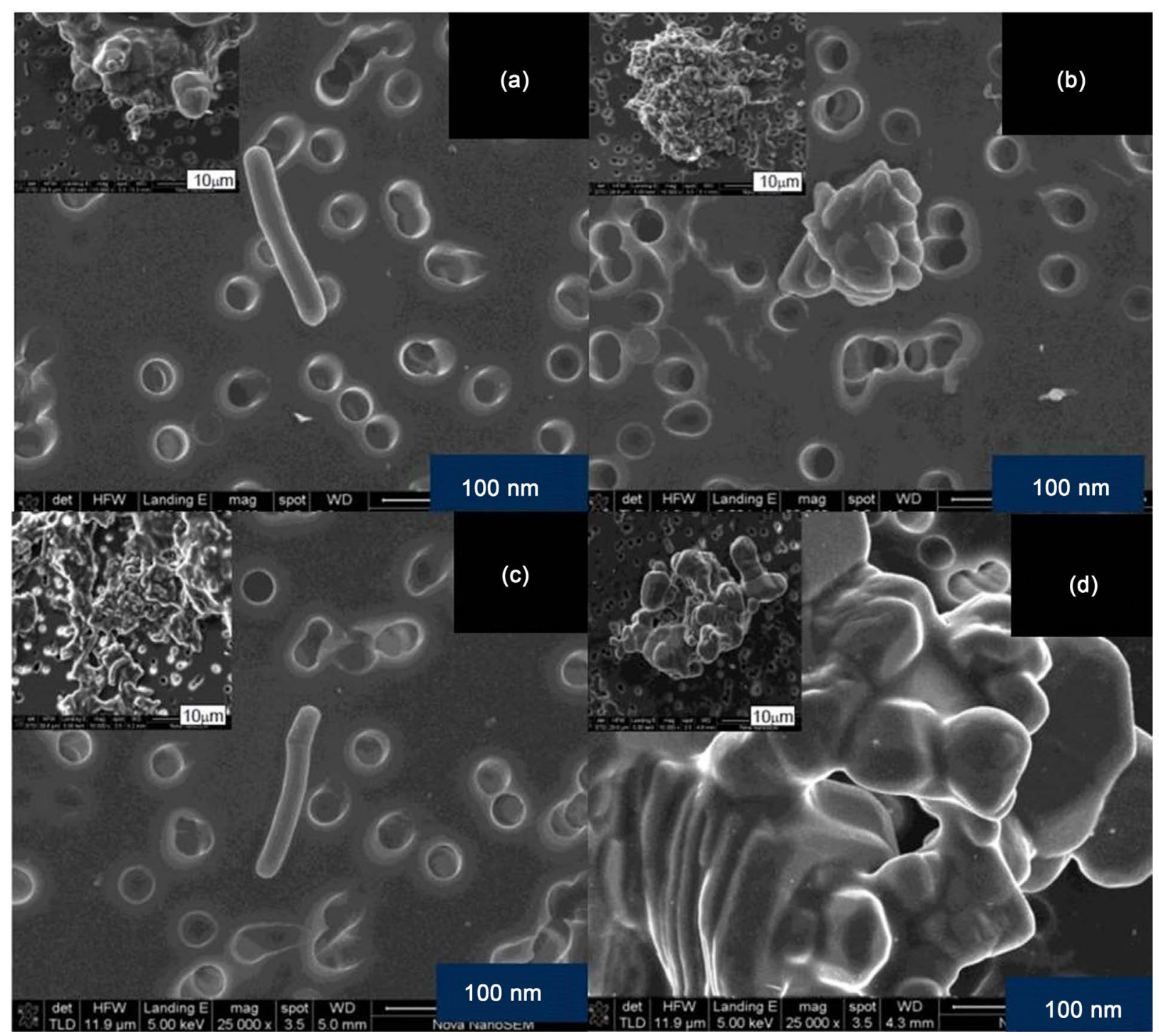

Figure 3. SEM images of pure and doped $\mathrm{CeO}_{2}$ (a) Pure $\mathrm{CeO}_{2}$, (b) $1 \% \mathrm{Cd}$, (c) $3 \% \mathrm{Cd}$, (d) $5 \% \mathrm{Cd}$.

various chemical methods [36] [37] [38].

\subsection{Cytotoxicity Analysis of MCF-7, A549 and Hep2 Cell Line}

The cytotoxic effect of $\mathrm{Cd}$ doped $\mathrm{CeO}_{2}$ NPs was examined in cultured (MCF-7, A549 and Hep-2) cell line by exposing cells for 72 hours. The cultured medium of $\mathrm{Cd}$ doped $\mathrm{CeO}_{2} \mathrm{NPs}$ led to inhibition at the various concentrations (10 to 100 $\mu \mathrm{g} / \mathrm{ml}$ as shown in Figure 8. The cancer cell viability is decreased partially with increasing the concentration of $\mathrm{Cd}$ doped $\mathrm{CeO}_{2}$ NPs. The results show the dose-response relationship with tested cells only at higher concentrations, but there is no significant toxicity [39].

\subsection{Morphological Cross Section of Apoptotic Cells by DAPI Staining and A0/EtBr Double Staining}

Acridine orange $(\mathrm{AO}) /$ Ethidium Bromide (EtBr) staining and DAPI staining 


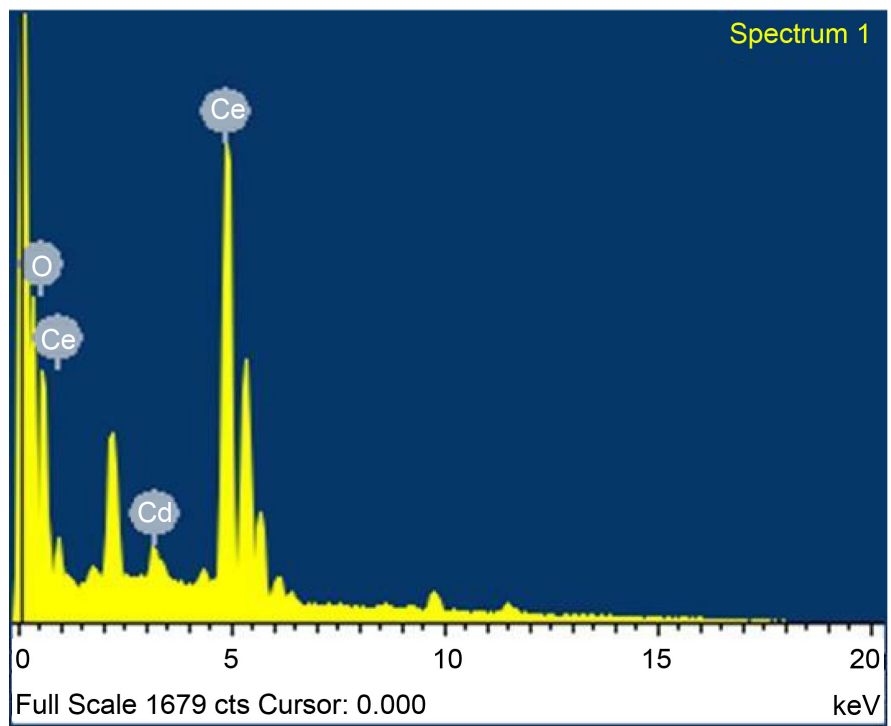

Figure 4. EDX analysis of $5 \% \mathrm{Cd}$ doped $\mathrm{CeO}_{2}$.

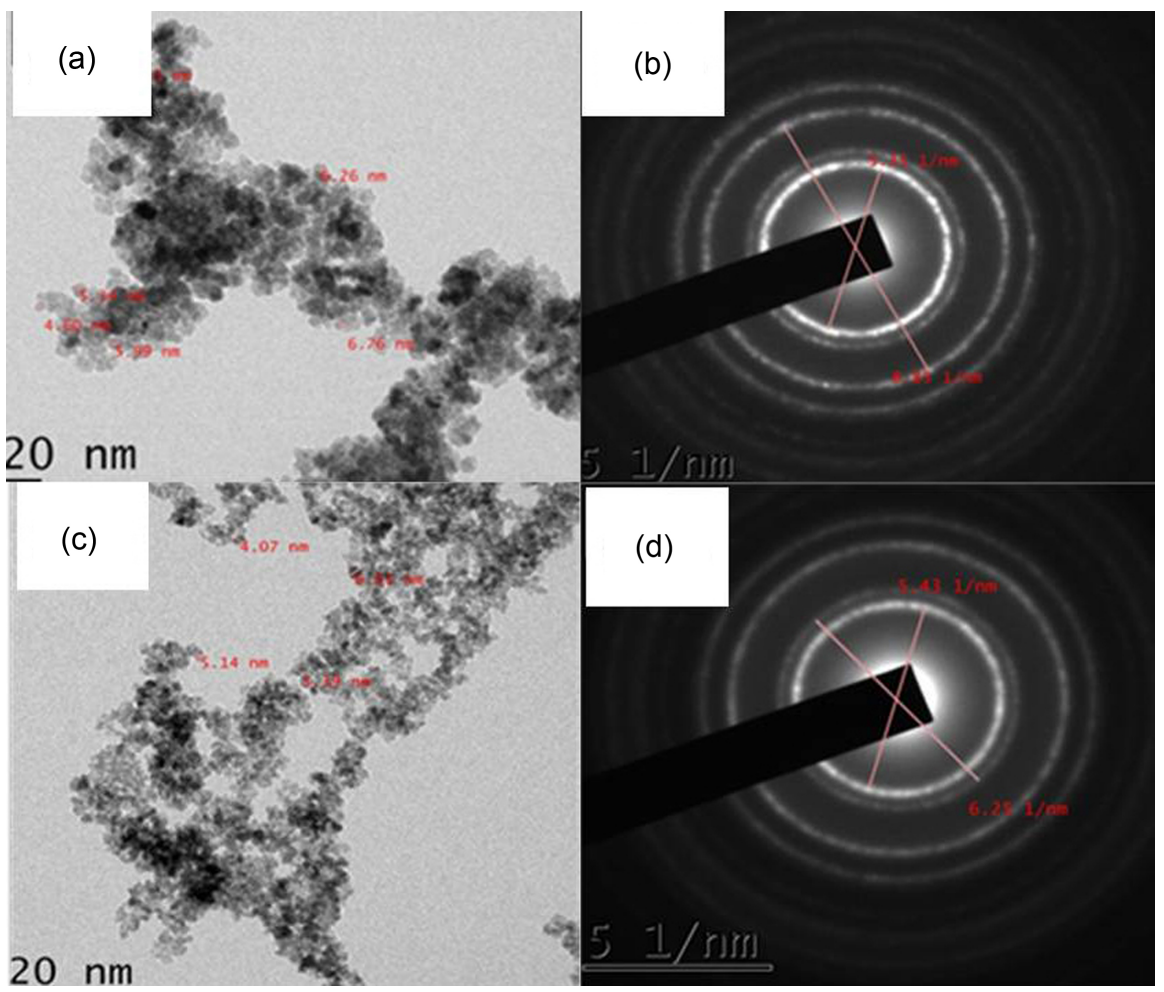

Figure 5. HRTEM images of pure and doped $\mathrm{CeO}_{2}$. (a) Pure $\mathrm{CeO}_{2}$, (b) SAED pattern of pure $\mathrm{CeO}_{2}$, (c) $3 \% \mathrm{~cd}$, and (d) SAED pattern of cd doped $\mathrm{CeO}_{2}$.

methods were utilized to study morphological evidence of apoptosis on the $\mathrm{Cd}$ doped $\mathrm{CeO}_{2}$ treated cells. From Figure 9, it is very clear that the apoptosis was noticed with the morphological changes in the cell shape. Points at that there morphological change are because of the activation of caspase cascades. We found that the cells were regular in morphology and they have grown fully in patches in the control group. However, after the treatment, the cells started 


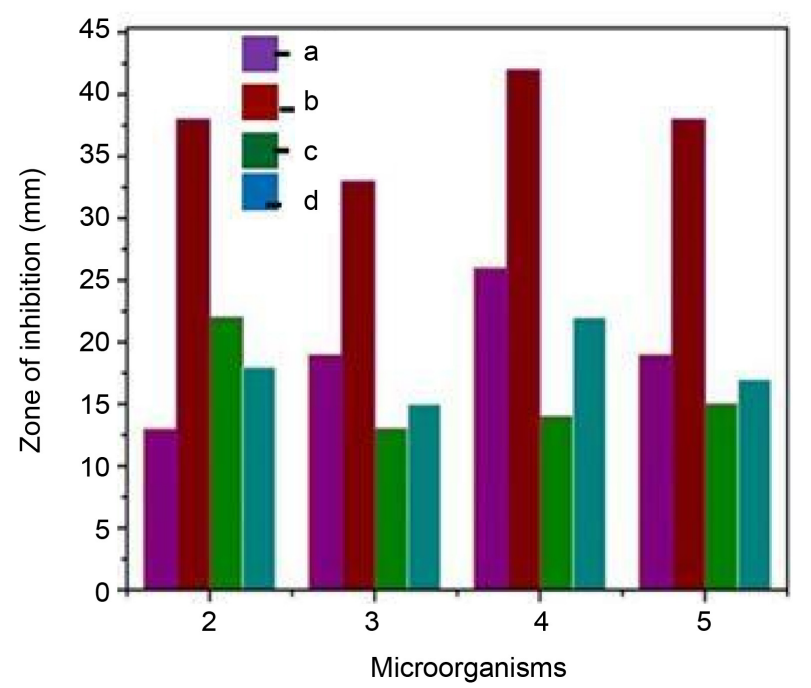

Figure 6. Antibacterial activity of $\mathrm{CeO}_{2} \mathrm{NPs}$ containing: (a) Pure, (b) $1.0 \%$, (c) $3.0 \%$, and (d) $5.0 \%$ of Cd.

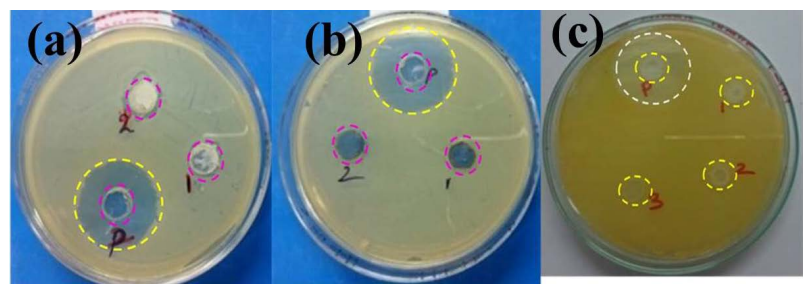

Figure 7. Zone of inhibition values for different concentration doped $\mathrm{CeO}_{2}$ NPs containing: Gram-positive [ $S$. aureus (a)] and Gram-negative [E. coli (b), P. aeruginosa (c)] Pure (P), $1.0 \%$ (1), $3.0 \%(2)$, and $5.0 \%$ (3) of Cd.

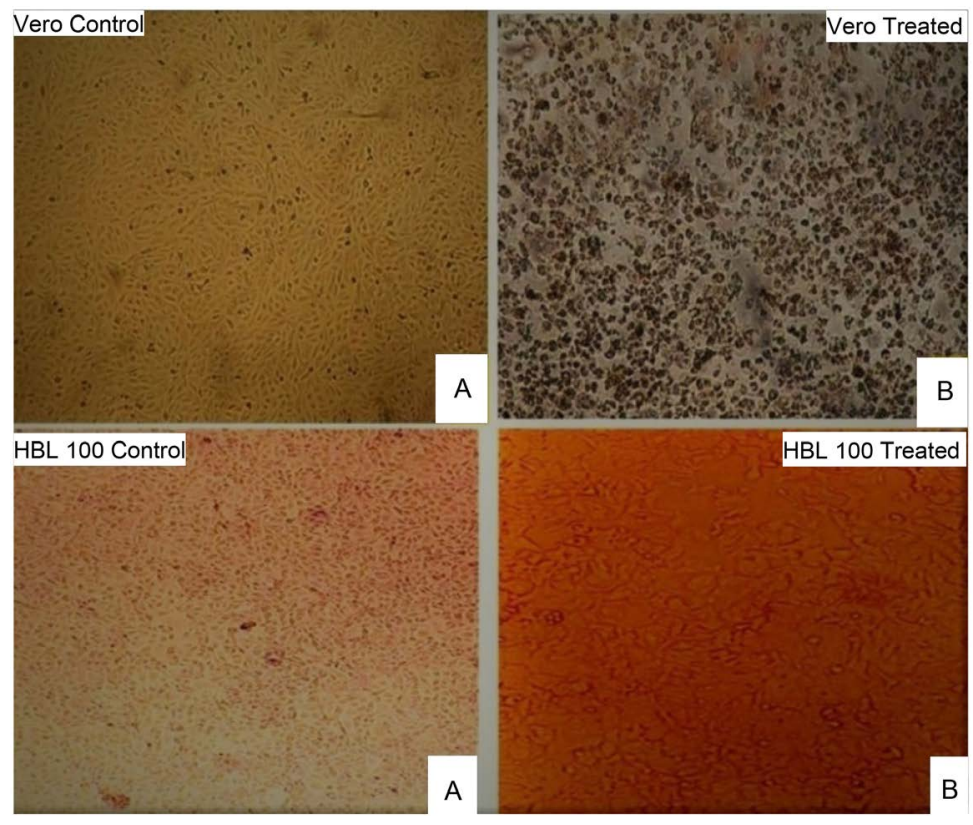

Figure 8. Vero and HBL 100 cell lines: (A) Control Cells. (B) Cd doped $\mathrm{CeO}_{2}$ NPs Treated at the cell lines. 


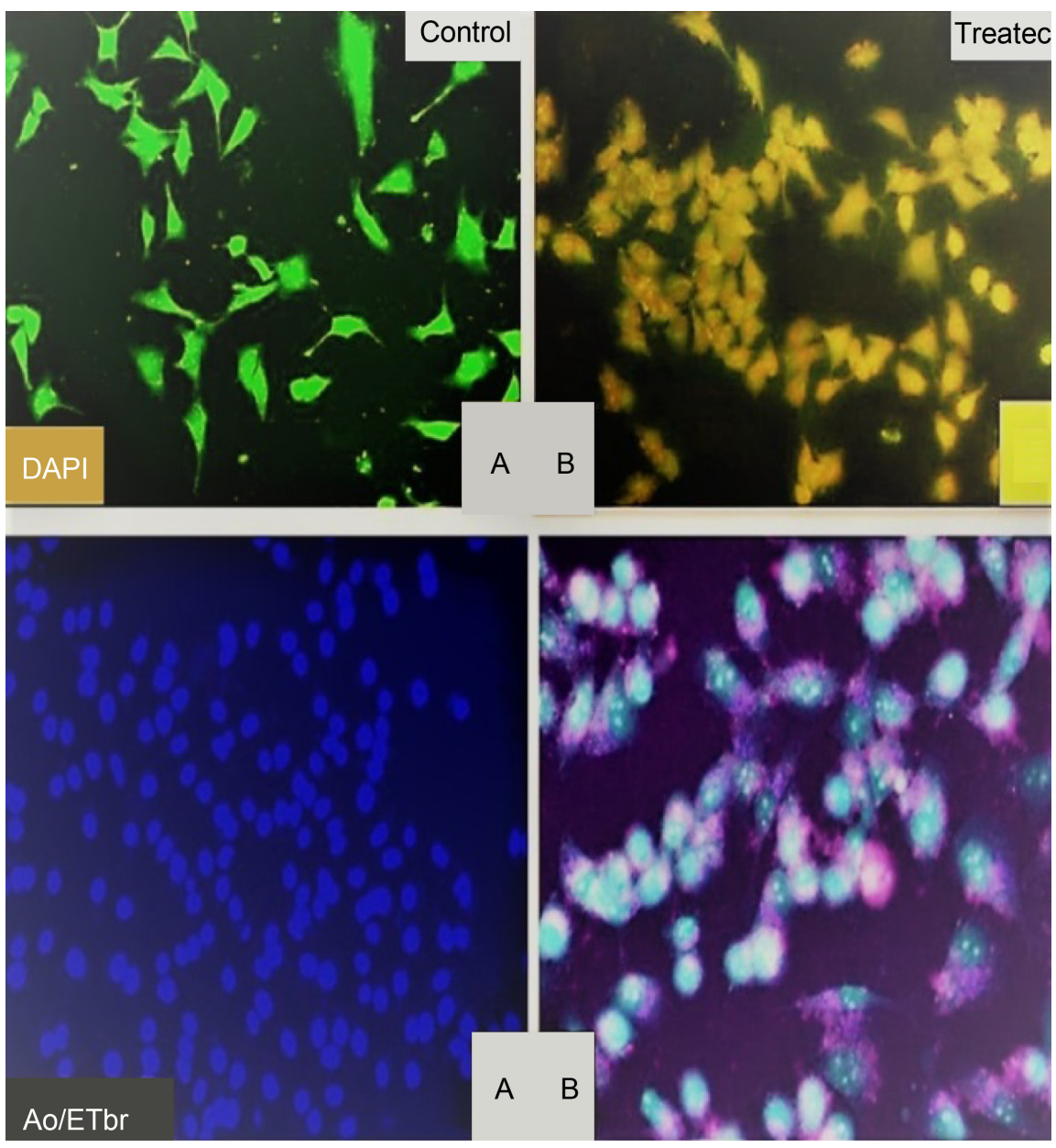

Figure 9. Cells treated with (A) control (B) $\mathrm{Cd}$ doped $\mathrm{CeO}_{2} \mathrm{NPs}$ at the respective $\mathrm{IC}_{50}$ concentrations and the morphologies Observed after staining with DAPI and Ao/EtBr.

exhibiting the apoptotic characteristics of nuclear condensation, cell shrinkage and fragmentation [40]. Further, the DAPI staining also revealed an increase in the number of apoptotic treated cells in terms of both nuclear condensation and cell structure loss [41] [42] [43]. Cd-doped $\mathrm{CeO}_{2}$ nanoparticles possess a fair control of the pathogenic activity. The cytotoxicity activity of Cd-doped $\mathrm{CeO}_{2}$ was also assessed for the cell lines MCF-7, A549 and Hep2 and the typical IC $_{50}$ values are tabulated in Table 1 . The obtained values have been compared with literature values reported for HT29 and SW620 cells using pure $\mathrm{CeO}_{2}$ nanoparticles.

The cytotoxic effects of pure and $\mathrm{Cd}$-doped $\mathrm{CeO}_{2}$ nanoparticles suggest that they can be used for the development of drugs against colorectal cancer. The apoptotic potential $\mathrm{CeO}_{2}$ nanoparticles upon doping with $\mathrm{Cd}$ ions were studied in breast cancer cell line MCF-7. A characteristic change in chromatic condensation and nuclear fragmentation has been observed which indicates the mechanism of cell death induced by the Cd-doped $\mathrm{CeO}_{2} \mathrm{NPs}$. A similar kind of study made for pure $\mathrm{CeO}_{2} \mathrm{NPs}$ for HT29 cells [44] in the expression levels of Bcl2 and $\mathrm{BclxL}$ proteins. In both cases, it has been confirmed that nanoparticles of $\mathrm{CeO}_{2}$ 
Table 1. Cytotoxicity of Cd-doped $\mathrm{CeO}_{2}$ in MCF-7, A549 and Hep2 cells.

\begin{tabular}{|c|c|c|c|}
\hline Sl. No. & Compound & Cell lines & $\mathrm{IC}_{50}$ values \\
\hline 1 & $\mathrm{CeO}_{2} \mathrm{NPs}$ & $\begin{array}{l}\text { MCF-7 } \\
\text { A549 } \\
\text { Hep2 }\end{array}$ & $\begin{array}{c}47.6 \\
48.2 \text { (present work) } \\
47.1\end{array}$ \\
\hline 2 & Cd doped $\mathrm{CeO}_{2} \mathrm{NPs}$ & $\begin{array}{l}\text { MCF-7 } \\
\text { A549 } \\
\text { Hep2 }\end{array}$ & $\begin{array}{c}70 \mu \mathrm{g} / \mathrm{ml} \\
70 \mu \mathrm{g} / \mathrm{ml} \text { (present work) } \\
70 \mu \mathrm{g} / \mathrm{ml}\end{array}$ \\
\hline 3 & $\mathrm{CeO}_{2} \mathrm{NPs}$ & $\begin{array}{c}\text { HT29 } \\
\text { SW620 }\end{array}$ & $50 \mu \mathrm{g} / \mathrm{ml}[36]$ \\
\hline
\end{tabular}

have the capacity of reducing cell proliferation.

\section{Conclusion}

Nanocrystalline forms of cerium oxide and cadmium doped cerium oxide have been successfully synthesized using chemical precipitation method. From XRD analysis, it was ascertained that the incorporation of cadmium ions did not alter the unit cell structure of $\mathrm{CeO}_{2}$ for all concentrations of dopant's viz 1\%, 3\% and $5 \%$. As per Debye-Scherrer's calculations, the average particle size of Cd-doped $\mathrm{CeO}_{2}$ was estimated to be in the range $8-10 \mathrm{~nm}$. Raman spectrum of Cd-doped $\mathrm{CeO}_{2}$ showed that no new bands formed due to the dopant ions. This implied that the possible modes of scattering vibrations for fluorite type of cubic structure could also be seen in the $\mathrm{Cd}$-doped $\mathrm{CeO}_{2}$ which in turn reciprocates the results obtained from XRD. SEM-EDAX measurements revealed the actual compositions of cadmium ions in the $\mathrm{CeO}_{2}$ matrix. Dopant has also influenced in transforming large aggregate particles into fine ones. However, agglomeration is also observed in doped samples as that of pure $\mathrm{CeO}_{2}$. HRTEM analysis on pure and $\mathrm{Cd}$-doped $\mathrm{CeO}_{2}$ brings out the fact that the decrease in the particle size upon an increase in the dopant concentration. SAED patterns provide additional confirmation of restoration crystal structure by $\mathrm{CeO}_{2}$ matrix even after doping. The minimal inhibitory concentration (MIC) behaviour of Cd-doped $\mathrm{CeO}_{2}$ nanoparticles has been assessed using gram-positive and gram-negative bacteria.

\section{Conflicts of Interest}

The authors declare that there is no conflict of interests regarding the publication of this manuscript.

\section{References}

[1] Wang, Y., Zi, XY., Su, J., Zhang, H.X., Zhang, X.R., Zhu, H.Y., Li, J.X., Yin, M., Yang, F. and Hu, Y.P. (2012) Cuprous Oxide Nanoparticles Selectively Induce Apoptosis of Tumor Cells. International Journal of Nanomedicine, 7, 2641-2652.

[2] Yang, F., Tang, Q., Zhong, X., Bai, Y., Chen, T., Zhang, Y., Li, Y. and Zheng W. (2012) Surface Decoration by Spirulina Polysaccharide Enhances the Cellular Uptake and Anticancer Efficacy of Selenium Nanoparticles. International Journal of 
Nanomedicine, 7, 835-844.

[3] Lee, P., Zhang, R., Li, V., Liu, X., Sun, R.W.Y., Che, C.-M. and Wong, K.K.Y. (2012) Enhancement of Anticancer Efficacy Using Modified Lipophilic Nanoparticle Drug Encapsulation. International Journal of Nanomedicine, 7, 731-737.

[4] Murphy, E.A., Majeti, B.K., Barnes, L.A., Makale, M., Weis, S.M., Lutu-Fuga, K., Wrasidlo, W. and Cheresh, D.A. (2008) Nanoparticle-Mediated Drug Delivery to Tumor Vasculature Suppresses Metastasis. Proceedings of the National Academy of Sciences, 105, 9343-9348. https://doi.org/10.1073/pnas.0803728105

[5] Siddiqui, I.A., Adhami, V.M., Chamcheu, J.C. and Mukhtar, H. (2012) Impact of Nanotechnology in Cancer: Emphasis on Nanochemoprevention. International Journal of Nanomedicine, 7, 591-605. https://doi.org/10.2147/IJN.S26026

[6] Ghadiali, J.E., Cohen, B.E. and Stevens, M.M. (2010) Protein Kinase-Actuated Resonance Energy Transfer in Quantum Dot-Peptide Conjugates. American Chemical Society Nano, 4, 4915-4919. https://doi.org/10.1021/nn101293s

[7] Wason, M.S. and Zhao, J. (2013) Cerium Oxide Nanoparticles: Potential Applications for Cancer and Other Diseases. American Journal of Translational Research, 5, 126-131.

[8] Lee, S.K., Kim, G.S., Wu, Y., Kim, D.J., Lu, Y., Kwak, M., Han, L., Hyung, J.H., Seol, J.K., Sander, C., Gonzalez, A., Li, J. and Fan, R. (2012) Nanowire Substrate-Based Laser Scanning Cytometry for Quantitation of Circulating Tumor Cells. Nano Letters, 12, 2697-2704. https://doi.org/10.1021/nl2041707

[9] Dicheva, B.M., ten Hagen, T.L., Li, L. Schipper, D., Seynhaeve, A.L., van Rhoon, G.C., Eggermont, A.M., Lindner, L.H. and Koning, G.A. (2013) Cationic Thermosensitive Liposomes: A Novel Dual Targeted Heat-Triggered Drug Delivery Approach for Endothelial and Tumor Cells. Nano Letters, 13, 2324-2331. https://doi.org/10.1021/nl3014154

[10] Kanapathipillai, M., Mammoto, A., Mammoto, T., Kang, J.H., Jiang, E., Ghosh, K., Korin, N., Gibbs, A., Mannix, R. and Ingber, D.E. (2012) Inhibition of Mammary Tumor Growth Using Lysyl Oxidase-Targeting Nanoparticles to Modify Extracellular Matrix. Nano Letters, 12, 3213-3217. https://doi.org/10.1021/nl301206p

[11] Zhao, G. and Rodriguez, B.L. (2013) Molecular Targeting of Liposomal Nanoparticles to Tumor Microenvironment. International Journal of Nanomedicine, 8, 61-71.

[12] Wang, Y., Yang, F., Zhang, H.X., Zi, X.Y., Pan, X.H., Chen, F., Luo, W.D., Li, J.X., Zhu, H.Y. and Hu, Y.P. (2013) Cuprous Oxide Nanoparticles Inhibit the Growth and Metastasis of Melanoma by Targeting Mitochondria. Cell Death and Disease, 4 , 783. https://doi.org/10.1038/cddis.2013.314

[13] Heckert, E.G., Karakoti, A.S., Seal, S. and Self, W.T. (2008) The Role of Cerium Redox State in the SOD Mimeticactivity of Nanoceria. Biomaterials, 29, 2705-2709. https://doi.org/10.1016/j.biomaterials.2008.03.014

[14] Hirano, M. and Kato, E. (1996) Hydrothermal Synthesis of Cerium (IV) Oxide. Journal of the American Ceramic Society, 79, 777-780. https://doi.org/10.1111/j.1151-2916.1996.tb07943.x

[15] Sathyaseelan, B., Sambasivam, S., Alagesan, T. and Sivakumar, K. (2014) EX-Situ Studies on Calcinations of Structural, Optical and Morphological Properties of Post-Growth Nanoparticles $\mathrm{CeO}_{2}$ by HRTEM and SAED. International Journal of Nano Dimension, 5, 341-349. https://doi.org/10.7508/IJND.2014.04.005

[16] Kaviyarasu, K., Manikandan, E., Nuru, Z.Y. and Maaza, M. (2017) Synthesis and Characterization Studies of $\mathrm{Pb}: \mathrm{Zr}: / \mathrm{O}_{2}$ Nanorods for Optoelectronic Applications. 
Journal of Nanomaterials \& Molecular Nanotechnology, 3, 10-80.

[17] Kaviyarasu, K., Fuku, X., Mola, G.T., Manikandan, E., Kennedy, J. and Maaza, M. (2016) Photoluminescence of Well-Aligned $\mathrm{ZnO}$ Doped $\mathrm{CeO}_{2}$ Nanoplatelets by a Solvothermal Route. Materials Letters, 183, 351-354.

https://doi.org/10.1016/j.matlet.2016.07.143

[18] Chauhan, S. and Upadhyay, M.K. (2012) Fruit Based Synthesis of Silver Nanoparticles-An Effect of Temperature on the Size of Particles. Recent Research in Science and Technology, 4, 41-44.

[19] Bhowmik, D., Sampath Kumar, K.P., Yadav, A., Shweta, S., Paswan, S. and Amit Sankar, D. (2012) Recent Trends in Indian Traditional Herbs Syzygium aromaticum and Its Health Benefits. Journal of Pharmacognosy and Phytochemistry, 1, 13-22.

[20] Inbathamizh, L., Mekalai Ponnu, T. and Janancy Mary, E. (2013) In Vitro Evaluation of Antioxidant and Anticancer Potential of Morinda pubescens Synthesized Silver Nanoparticles. Journal of Pharmacy Research, 6, 32-38.

https://doi.org/10.1016/j.jopr.2012.11.010

[21] Mosmann, T. (1983) Rapid Calorimetric Assay for Cellular Growth and Survival: Application to Proliferation and Cytotoxicity Assays. Journal of Immunological Methods, 65, 55-63. https://doi.org/10.1016/0022-1759(83)90303-4

[22] Krishnaraj, C., Jagan, E.G., Rajasekar, S., Selvakumar, P., Kalaichelvan, P.T. and Mohan, N. (2010) Synthesis of Silver Nanoparticles Using Acalypha indica Leaf Extracts and Its Antibacterial Activity against Water Borne Pathogens. Colloids and Surfaces B: Biointerfaces, 76, 50-56. https://doi.org/10.1016/j.colsurfb.2009.10.008

[23] Kroemer, G., Zamzami, N. and Susin, S.A. (1997) Mitochondrial Control of Apoptosis. Immunology Today, 18, 44-51. https://doi.org/10.1016/S0167-5699(97)80014-X

[24] Spector, D.L., Goldman, R.D. and Leinwand, L.A. (1998) Cells: A Laboratory Manual. Cold Spring Harbor Laboratory, New York.

[25] Krishnaraj, C., Muthukumaran, P., Ramachandran, R., Balakumaran, M.D. and Kalaichelvan, P.T. (2014) Acalypha indica Linn: Biogenic Synthesis of Silver and Gold Nanoparticles and Their Cytotoxic Effects against MDA-MB-231, Human Breast Cancer Cells. Biotechnology Reports, 4, 42-49. https://doi.org/10.1016/j.btre.2014.08.002

[26] Papi, A., Farabegoli, F., Iori, R., Orlandi, M., De Nicola, G.R., Bagatta, M., Angelino, D., Gennari, L. and Ninfali, P. (2013) Vitexin-2-O-Xyloside, Raphasatin and (-)-Epigallocatechin-3-Gallate Synergistically Affect Cell Growth and Apoptosis of Colon Cancer Cells. Food Chemistry, 138, 1521-1530. https://doi.org/10.1016/j.foodchem.2012.11.112

[27] Inbathamizh, L., Mekalai Ponnu, T. and Janancy, M. (2013) In Vitro Evaluation of Antioxidant and Anticancer Potential of Morinda pubescens Synthesized Silver Nanoparticles. Journal of Pharmacy Research, 6, 32-38. https://doi.org/10.1016/j.jopr.2012.11.010

[28] Qi, Y., Wen, H., Zhang, W., Song, Y.Q., Yang, Q.H., Zhu, H. and Xiao, J.Q. (2007) Room-Temperature Ferromagnetism in Pure and Co Doped $\mathrm{CeO}_{2}$ Powders. Journal of Physics. Condensed Matter, 19, Article ID: 246205.

[29] Kumar, S., Kim, Y.J., Koo, B.H. and Lee, C.G. (2009) Structural and Magnetic Properties of Co Doped $\mathrm{CeO}_{2}$ Nano-Particles. IEEE Transactions on Magnetics, 45, 2439-2441. https://doi.org/10.1109/TMAG.2009.2018602

[30] Thurber, A., Reddy, K.M., Shutthanandan, V., Engelhard, V.H., Wang, C., Hays, J. and Punnoose, A. (2007) Ferromagnetism in Chemically Synthesized $\mathrm{CeO}_{2}$ 
Nanoparticles by Ni Doping. Physical Review B, 76, Article ID: 165206. https://doi.org/10.1103/PhysRevB.76.165206

[31] Plug, H.P. and Alexander, L.E. (1954) X-Ray Diffraction Procedures for Polycrystalline and Amorphous Material. Wiley, New York.

[32] Arias, M.A., Garcia, F.M., Salamanca, L.N., Valenzuela, R.X., Conesa, J.C. and Soria, J. (2000) Structural and Redox Properties of Ceria in Alumina-Supported Ceria Catalyst Supports. The Journal of Physical Chemistry B, 104, 4038-4046. https://doi.org/10.1021/jp992796y

[33] Shyu, J.Z., Weber, W.H. and Gandhi, H. (1988) Surface Characterization of Alumina-Supported Ceria. The Journal of Physical Chemistry, 92, 4964-4970. https://doi.org/10.1021/j100328a029

[34] Lin, X.M., Li, L.P., Li, G.S. and Su, W.H. (2001) Transport Property and Raman Spectra of Nanocrystalline Solid Solutions $\mathrm{Ce}_{0.8} \mathrm{Nd}_{0.2} \mathrm{O}_{2-\delta}$ with Different Particle Size. Materials Chemistry and Physics, 69, 236-240. https://doi.org/10.1016/S0254-0584(00)00409-0

[35] Weber, W.H., Hass, K.C. and McBride, J.R. (1993) Raman Study of $\mathrm{CeO}_{2}$ : Second-Order Scattering, Lattice Dynamics, and Particle-Size Effects. Physical Review $B, 48,178-185$. https://doi.org/10.1103/PhysRevB.48.178

[36] Lima, R., Seabra, A.B. and Durán, N. (2012) Silver Nanoparticles: A Brief Review of Cytotoxicity and Genotoxicity of Chemically and Biogenically Synthesized Nanoparticles. Journal of Applied Toxicology, 32, 867-879. https://doi.org/10.1002/jat.2780

[37] Abbas, F., Iqbal, J., Jan, T., Sajjad, M., Gul, A., Abbasi, R., Mahmood, A., Ahmad, I. and Ismail, M. (2015) Differential Cytotoxicity of Ferromagnetic Co Doped CeO Nanoparticles against Human Neuroblastoma Cancer Cells. Journal of Alloys and Compounds, 648, 1060-1066. https://doi.org/10.1016/j.jallcom.2015.06.195

[38] Khan, S., Anees, A., Ansari, A.A., Ahmad, R., Al-Obaid, O. and Al-Kattan, W. (2015) In Vitro Evaluation of Anticancer and Antibacterial Activities of Cobalt Oxide Nanoparticles. Journal of Biological Inorganic Chemistry, 20, 1319-1326. https://doi.org/10.1007/s00775-015-1310-2

[39] Gopinath, K., Chinnadurai, M., Devi, N.P., Bhakyaraj, K., Kumaraguru, S., Baranisri, T., Sudha, A., Zeeshan, M., Arumugam, A., Govindarajan, M., Alharbi, N.S., Kadaikunnan, S. and Benelli, G. (2017) One-Pot Synthesis of Dysprosium Oxide Nano-Sheets: Antimicrobial Potential and Cyotoxicity on A549 Lung Cancer Cells. Journal of Cluster Science, 28, 621-635. https://doi.org/10.1007/s10876-016-1150-4

[40] Arbab, I.A., Abdul, A.B., Sukari, M.A., Abdullah, R., Syam, S., Kamalidehghan, B., Ibrahim, M.Y., Taha, M.M.E., Abdelwahab S.I. and Ali, H.M. (2013) Dentatin Isolated from Clausena Excavate Induces Apoptosis in MCF-7 Cells through the Intrinsic Pathway with Involvement of NF- $k$ B Signalling and G0/G1 Cell Cycle Arrest: A Bioassay-Guided Approach. Journal of Ethnopharmacology, 145, 343-354. https://doi.org/10.1016/j.jep.2012.11.020

[41] West, J.L. and Halas, N.J. (2000) Applications of Nanotechnology to Biotechnology, Current Opinion in Biotechnology, 11, 215-217. https://doi.org/10.1016/S0958-1669(00)00082-3

[42] Alphandary, P.H., Andremont, A. and Couvreur, P. (2000) Targeted Delivery of Antibiotics Using Liposomes and Nanoparticles: Research and Applications. International Journal of Antimicrobial Agents, 13, 155-168. https://doi.org/10.1016/S0924-8579(99)00121-1

[43] Cleveland, J.L. and Kastan, M.B. (2000) Cancer-A Radical Approach to Treatment. 
Nature, 407, 309-311. https://doi.org/10.1038/35030277

[44] Khana, S., Al-Ansaric, A., Rolfod, C., Coelhod, A., Abdullae, M., Khayale, K.A. and Ahmade, R. (2017) Evaluation of in Vitro Cytotoxicity, Biocompatibility, and Changes in the Expression of Apoptosis Regulatory Proteins Induced by Cerium Oxide Nanocrystals. Science and Technology of Advanced Materials, 18, 364-373. https://doi.org/10.1080/14686996.2017.1319731 